\title{
Correction to: Evolutionary pattern of karyotypes and meiosis in pholcid spiders (Araneae: Pholcidae): implications for reconstructing chromosome evolution of araneomorph spiders
}

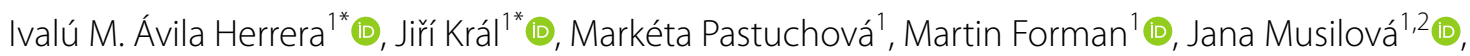

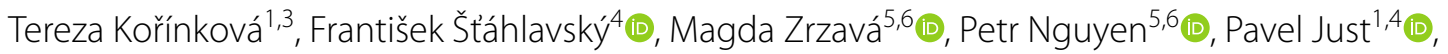
Charles R. Haddad ${ }^{7}$, Matyáš Hiřman ${ }^{4}$, Martina Koubová ${ }^{10}$, David Sadílek ${ }^{1,4}$ (i) and Bernhard A. Huber ${ }^{8}$ (i)

\section{Correction to: BMC Ecol Evol (2021) 21:75} https://doi.org/10.1186/s12862-021-01750-8

Following the publication of the original article [1], the authors notified us that Figure 16 contained a few incorrect question marks. These have been removed.

The original article has been corrected.

\section{Author details}

'Laboratory of Arachnid Cytogenetics, Department of Genetics and Microbiology, Faculty of Science, Charles University, Viničná 5, 12844 Prague 2, Czech Republic. ${ }^{2}$ Research Team of Plant Stress Biology and Biotechnology, Division, of Crop Genetics and Breeding, Crop Research Institute, Drnovská 507/73, 161 00 Prague 6, Czech Republic. ${ }^{3}$ Prague 1, Czech Republic. ${ }^{4}$ Invertebrate Zoology Unit, Department of Zoology, Faculty of Science, Charles University, Viničná 7, 12844 Prague 2, Czech Republic. ${ }^{5}$ Laboratory of Molecular Cytogenetics, Department of Molecular Biology and Genetics, Faculty of Science, University of South Bohemia, Branišovská 31, 37005 České Budějovice, Czech Republic. ${ }^{6}$ Laboratory of Molecular Cytogenetics, Department of Molecular Biology and Genetics, Institute of Entomology, Biology Centre CAS, Branišovská 31, 370
05 České Budějovice, Czech Republic. ${ }^{7}$ Research Group of Arachnid Systematics and Ecology, Department of Zoology and Entomology, Faculty of Natural and Agricultural Sciences, University of the Free State, P.O. Box 339, Bloemfontein 9300, Republic of South Africa. ${ }^{8}$ Arachnida Section, Alexander Koenig Zoological Research Museum, Adenauerallee 160, 53113 Bonn, Germany.

Published online: 21 May 2021

\section{Reference}

1. Ávila Herrera IM, Král J, Pastuchová M, Forman M, Musilová J, Kořínková T, Štáhlavský F, Zrzavá M, Nguyen P, Just P, Haddad CR, Hiřman M, Koubová $M$, Sadilek D, Huber BA. Evolutionary pattern of karyotypes and meiosis in pholcid spiders (Araneae: Pholcidae): implications for reconstructing chromosome evolution of araneomorph spiders. BMC Ecol Evol. 2021;21:75. https://doi.org/10.1186/s12862-021-01750-8.

\section{Publisher's Note}

Springer Nature remains neutral with regard to jurisdictional claims in published maps and institutional affiliations.

The original article can be found online at https://doi.org/10.1186/s12862021-01750-8.

\footnotetext{
*Correspondence: avilai@natur.cuni.cz; spider@natur.cuni.cz

${ }^{1}$ Laboratory of Arachnid Cytogenetics, Department of Genetics and Microbiology, Faculty of Science, Charles University, Viničná 5, 128 44 Prague 2, Czech Republic

Full list of author information is available at the end of the article
}

(C) The Author(s) 2021. Open Access This article is licensed under a Creative Commons Attribution 4.0 International License, which permits use, sharing, adaptation, distribution and reproduction in any medium or format, as long as you give appropriate credit to the original author(s) and the source, provide a link to the Creative Commons licence, and indicate if changes were made. The images or other third party material in this article are included in the article's Creative Commons licence, unless indicated otherwise in a credit line to the material. If material is not included in the article's Creative Commons licence and your intended use is not permitted by statutory regulation or exceeds the permitted use, you will need to obtain permission directly from the copyright holder. To view a copy of this licence, visit http://creativecommons.org/licenses/by/4.0/. The Creative Commons Public Domain Dedication waiver (http://creativeco mmons.org/publicdomain/zero/1.0/) applies to the data made available in this article, unless otherwise stated in a credit line to the data. 